\title{
Proposal of a Nomenclature for Hydrogeological Instability Risks and Case Studies of Conservative Soil Tillage for Environmental Protection
}

\author{
Davide Puccio $^{1}$, Antonio Comparetti ${ }^{1, *(\mathbb{D})}$, Carlo Greco ${ }^{2}$ and Salvatore Raimondi ${ }^{1}$ \\ 1 Department of Agricultural, Food and Forest Sciences, University of Palermo, 90128 Palermo, Italy; \\ davide.puccio@hotmail.it (D.P.); salvatore.raimondi@unipa.it (S.R.) \\ 2 Council for Agricultural Research and Economics (CREA), Research Centre Protection and Certification, \\ Bagheria, 90011 Palermo, Italy; carlo.greco@crea.gov.it \\ * Correspondence: antonio.comparetti@unipa.it; Tel.: +39-091-238-97057
}

check for

updates

Citation: Puccio, D.; Comparetti, A.; Greco, C.; Raimondi, S. Proposal of a Nomenclature for Hydrogeological Instability Risks and Case Studies of Conservative Soil Tillage for

Environmental Protection. Land 2022, 11, 108. https://doi.org/10.3390/ land 11010108

Academic Editors: Gergely Tóth, Eva Ivits and Bozena Smreczak

Received: 14 December 2021

Accepted: 6 January 2022

Published: 10 January 2022

Publisher's Note: MDPI stays neutral with regard to jurisdictional claims in published maps and institutional affiliations.

Copyright: (C) 2022 by the authors. Licensee MDPI, Basel, Switzerland. This article is an open access article distributed under the terms and conditions of the Creative Commons Attribution (CC BY) license (https:// creativecommons.org/licenses/by/ $4.0 /)$.

\begin{abstract}
In order to implement environmental protection, within the Soil Cadastre, previously proposed as a multipurpose inventory that aims to promote sustainable soil uses, the hydrogeological instability caused by human activities is the focus of this work. These activities can be aimed at sustainable agricultural soil use or the building of roads to allow the access to the fields. The soil's hydrogeological instability causes the unsustainable use and management of a cadastral parcel. Therefore, the aim of this work is to propose a nomenclature for hydrogeological instability risks, as well as the best practices of conservative soil tillage in case studies, in order to reduce environmental impact. According to the proposed Soil Cadastre, the missing environmental sustainability of a parcel and the reason for this must be communicated to the field owner or manager. In a hilly area of inland Western Sicily, four main risk types of hydrogeological instability were identified: hydrogeological instability (caused only by natural factors); hydraulic-pedological farming instability (crop not suitable for the field for missing or insufficient soil drainage and landslides); hydraulic-infrastructural instability (built up infrastructures unsuitable for the site); hydraulic-infrastructural-pedologicalmanagement instability (field improvements changing the downflow line and crop operations not suitable for the soil and climate parameters). The farm owner or manager must be informed about the risk type affecting their fields in order to perform the best practices (i.e., conservative soil tillage), for implementing or restoring a sustainable soil use or management in each cadastral parcel.
\end{abstract}

Keywords: soil management; sustainable development; environmental sustainability; Soil Cadastre; best practices; agricultural mechanisation

\section{Introduction}

Sustainable development is implemented when the use of resources, e.g., soil, water [1] and air, as well as economic investments, technological innovations and territorial policies satisfy the current and future needs of people [2]. Sustainable development is one of the main objectives aimed at remediating the damages and degradation of urban and suburban territories inflicted during the last five decades.

In urban territories, the sustainable planning of a green area must include a soil study to evaluate its chemical (e.g., organic matter, water and nutrients contents), physical (e.g., structure and texture) and physical-mechanical parameters (e.g., soil compaction) [3].

Both farmers and livestock breeders play a key role in environmentally sustainable soil use and crop management, as their actions can affect the health of the ecosystem where they work, the preservation of the essential services of the ecosystem itself, and the archaeological heritage [4,5].

In fact, it is paramount to preserve the soil-water-plant balance in ecosystems, in order to prevent their degradation [6]. Therefore, modern farmers must know the environmental 
parameters, in order to rationally work to preserve the balances of the soil commodities for future generations. Otherwise, unsustainable land and crop management could lead to environmental damages.

Hydrogeological instability is widespread in Sicily, in other regions of Italy and other countries, and it is often caused by unethical and unsustainable human activities. ISPRA (Higher Institute for Environmental Protection and Research) offers a high contribution to the knowledge on hydrogeological instability occurring in Italy, by updating the dangers of landslides and floods. A 2020 report by ISPRA shows that $91 \%$ of municipalities are in danger of landslides and/or floods, $16 \%$ of Italian territory is considered to be in high danger, 1.28 million (2.2\% of total amount) inhabitants are in danger of landslides, and 6.18 million (10.4\% of the total amount) inhabitants are in danger of flood [7].

Unfortunately, the current Soil Cadastre is not a model of soil inventory for environmental, social, economic and taxation purposes in a globalised market, such as the model proposed by Raimondi [5]. This innovative Soil Cadastre is aimed at environmental protection and sustainable soil use: a farm owner who implements sustainable crop management and soil use in their fields could be awarded an allowance as a prize.

Therefore, the aim of this work is, within the previously proposed Soil Cadastre, to outline three case studies of three different types of hydrogeological instability risks, in order to propose a nomenclature for these risks, together with the best practices of soil management for each type.

This review is structured as follows:

- The theoretical background on Soil Cadastre for environmental protection;

- Hydrogeological instability;

- $\quad$ Case studies of hydrogeological instability;

- The nomenclature proposed for hydrological instability risks;

- The implementation of the proposed nomenclature of hydrological instability risks within Soil Cadastre.

\section{Theoretical Background on Soil Cadastre for Environmental Protection}

Some scientists characterised soil resources from all over the world $[8,9]$, and used methods for estimating some pedogenesis processes to determine soil age [10]. These researchers characterised newly discovered, expandable minerals (influencing soil fertility) [11], soil organic matter and carbon sequestration in the soil itself [12-16], using an online method to add the soil information in Soil Cadastre, useful for both soil use planners and field managers [17]. As soil information includes within-field, spatially variable crop and soil parameters, sensors for measuring these parameters, GNSS (e.g., GPS, GLONASS and EGNOS) mobile receivers and GIS (Geographic Information System) software are needed for mapping them [18-20].

Moreover, the farmers must know the spatial variability of within-field crop and soil parameters, by means of specific sensors and GNSS (Global Navigation Satellite Systems) receivers [21] or remote sensing, in order to produce soil maps by means of GIS software. In this regard, they need to know the best mechanised agricultural practices for soil conservation, e.g., minimum and zero soil tillage [22-26].

Soil surveys are fundamental for optimising crop operations, in order to preserve soil fertility and yield. A land evaluation provides field owners or managers with the optimal potential soil uses, preventing or remediating soil degradation [27], as well as the possible agronomic improvements and eventual negative effects [28]. In this regard, experienced farmers can transform some limiting soil parameters, e.g., salinity, in specific soil uses, e.g., the cultivation of Nero d'Avola vine cultivar for high-quality wine production [29].

The previously proposed Soil Cadastre is an instrument mainly aimed at promoting sustainable soil uses, as well as their management and CAP (Common Agricultural Policy), in order to reduce environmental impacts $[5,17,30,31]$. Within this Soil Cadastre, the detailed information included in the Soil Cadastral Certificate allows agronomists and farmers to immediately evaluate sustainable soil uses, by means of land capability, in 
order to maintain soil productivity and satisfy the needs of the present and future local communities.

The suburban Soil Cadastre implies a renovation of the Soil Cadastral Certificate: other information, i.e., territorial and environmental parameters, as well as soil use, are included in this certificate [5].

If the previously proposed Soil Cadastre is implemented, the following principle must be applied: "Who causes damages must remediate them in the shortest time as possible, while who implements sustainable soil uses must be rewarded". A clear and summarised communication to soil owners and managers is needed in order to communicate the principles of sustainability of the previously proposed Soil Cadastre.

\section{Hydrogeological Instability}

Hydrogeological risk belongs to the four categories of environmental risk, together with weather, volcanic and seismic ones. An environmental risk occurs when a natural event causes significant damages to people and their economics and can be computed by multiplying the danger by the vulnerability of a territory [32]. The danger is the probability that an event occurs with an intensity and size higher or equal to a default limit, while the vulnerability is the degree of sensitivity to an environmental event of determined intensity. Hydrogeological instability was defined by Gisotti [33] as a disease of civilisation: humanity accelerated the speed of natural events that otherwise would be slower, so they became natural disasters caused by humans.

The Mediterranean climate fosters the occurrence of hydrogeological instability because it is characterised by rainy winters and dry summers. These events almost always occur in mostly clay soils existing along hilly and mountain slopes and, above all, where layers of siliceous sandstones are alternated with marls or clays when rains of high intensity happen over a short period. These events are more intense if an appropriate soil reclamation is not carried out; a continuous coverage of soil surface is not guaranteed, drainage lines allowing water downflow along slopes are not dug, etc. All territory transformations, building up villages and infrastructures, and unauthorised development, without respecting the environmental limits, become an obstacle to water downflow. Moreover, infrastructures change the permeability of the soil surface by decreasing the infiltration of rainwater and increasing the speed of surface downflow. Hydrogeological instability causes events that can be distinguished in surface erosion, landslides, floods and water stagnation. Surface erosion, caused by water, is the transport of soil mass from the top to the bottom of a slope. The first step of this kind of instability is erosion, which can occur in different ways: layer erosion, rill erosion, gully erosion and, finally, the formation of ravines, nowadays widespread in Sicily. A landslide can be defined as deep erosion or mass movement, as it concerns a higher soil thickness. Its main causes are site geology, topography, gradient, overloads due to water, plant presence and growth, human buildings, traffic of vehicles, earthquakes, etc. Additionally, digging out the bottom of the slope carved by rivers and streams, as well as side pushes, e.g., those caused by the swelling of clay soil mass, can cause landslides. The following types of landslides can occur: collapse landslide (free falling down and stockpiling at the bottom); overturning landslide (rotation of a mass around a point below its centre of gravity); rotational slip landslide (movement of the soil mass along the surface); translation slip landslide (same as the previous one but concerning a larger surface); enlargement landslide (surface enlargement through fractures); and drainage landslide (continuous deformation of loose materials). Another event of hydrogeological instability is flooding, i.e., "temporary flooding of areas that are not usually covered by water" [34]. The overflow occurs after "a rainy event having exceptional intensity and time, however higher than the average" [33]. The factors influencing surface downflow are: the path that water must follow inside the hydrographic basin; gradient; natural or artificial obstacles existing in the hydrographic network; time needed for filling up the existing reservoirs; and basin area and shape. During the downflow, solid materials existing in the riverbed are transported via suspension or rolling, according to their weight and size. 
These events can cause extensive damage such as the breaking of banks, damage to crop production, infrastructures, dwellings and their inhabitants, as well as changes in the soil parameters, because of the deposit of the transported materials. Yet, flooding can improve soil fertility, which man can use. Among the types of hydrogeological instability, there is also water stagnation, occurring when the water coming from rains, raising of aquifers or floods submerges the soil by removing its air. This event generally happens in flat soils of any texture, although clay soils are the most sensitive to this.

Moreover, in some cases of hydrogeological instability, when up-down ploughing or contour ploughing by rotating the soil slice downstream is carried out on a hilly field, soil erosion becomes prominent [35-42].

In order to prevent or minimise soil compaction and erosion, many scientists proposed techniques of conservative soil tillage, by implementing different methods aside from ploughing [43], e.g., subsoiler [44], rotary tiller and chisel plough [45].

\section{Case Studies of Hydrogeological Instability}

Three case studies were selected in three sites of a hilly area of inland Western Sicily, located in the territory of Corleone (Palermo, Sicily, Italy). These case studies provided the input data needed for obtaining the work results, i.e., the hydrogeological instability risks observed during some surveys, on which the nomenclature proposed for these risks is based.

The excerpt of the Map of Instability n. 19 (Sicilian Region - Territory and Environment Department, Basin Shred Plan for Hydrogeological Layout, 2005) including the above area is shown in Figure 1.

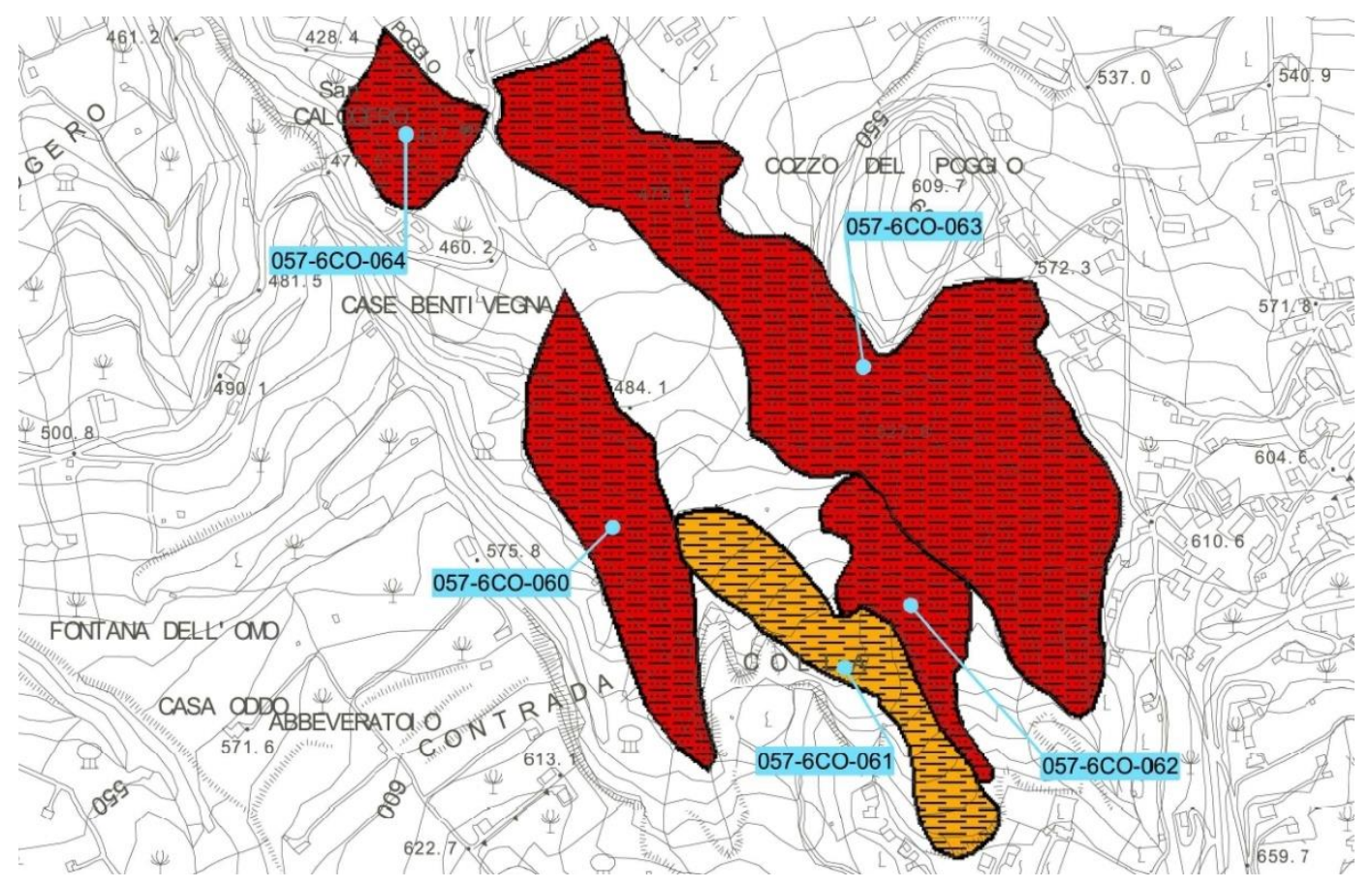

Figure 1. Hydrographic basin of Belice river (057)—excerpt of the Map of Instability n. 19, including the surveyed area (Sicilian Region-Territory and Environment Department, Basin Shred Plan for Hydrogeological Layout, 2005): the areas where soil erosion caused landslides are highlighted, i.e., those having active landslides are in red colour, while those having landslides at rest are in yellow colour.

From March to September 2015, surveys were carried out in this area to identify the human activities that caused hydrogeological instability. 
Thus, it was possible to focus on the unethical human activities that reduced the productivity of soils and caused damages to their infrastructures.

The above three case studies were selected for the surveys, as they are characterised by three different types of hydraulic instability risk:

- $\quad$ At the first site, a landslide was observed on a hilly slope (arable land) cultivated with a cereal and legume (Italian sainfoin) crop rotation;

- $\quad$ At the second site, an area degraded because of flooding, gully erosion and water stagnation was observed;

- $\quad$ At the third site, the damages caused by incorrect crop operations, implemented for an unsustainable field improvement (not suitable for the natural conditions of the hydrographic network), were observed.

The surveyed area is located at an altitude between 500 and $700 \mathrm{~m}$ a.s.l. (Figure 2).



Figure 2. View of the surveyed area.

This area has a yearly mean temperature of $16.19^{\circ} \mathrm{C}$, with a mean summer temperature of $24.1^{\circ} \mathrm{C}$ and a mean winter temperature of $9.07^{\circ} \mathrm{C}$ [46]. The yearly mean rainfall is $654 \mathrm{~mm}$ (or $700 \mathrm{~mm}$ according to the period), concentrated in autumn and winter (70\% ca.). The monthly rainfall is between 6-10 mm (June and July) and 90-100 mm (December and January). The climate is temperate from September to May, while from June to August it is arid. According to Thornthwaite, this climate ranges from sub-humid to sub-arid, second mesothermal (C1B2). The climate is characterised by warm and slightly rainy summers and mild winters. The snow does not cover the surveyed area for more than 1-2 days. In the last three decades, dry and very rainy years were recorded in this territory with both extreme rainfall (water bombs) and summer heat waves.

In this area, soils are mostly clay and calcareous, specifically Vertisols and Inceptisols. Entisols are slightly distributed where floods occur and on tender and hard rocks. The soils generally originate after a long pedogenesis and often have a high depth. At the top of these hilly slopes, the rocks are characterised by calcarenite formations, i.e., Calcarenite of Corleone of superior Burdigalian and inferior Langhian. The water is conveyed along these hilly slopes to underground aquifers emerging in contact with the below clay formation of inferior Miocene, constituted by a marl-sandstone formation, i.e.Marls of San Cipirello. Elsewhere, deposits of middle or Tortonian Miocene, constituted by river sediments, e.g., conglomerates, gravel and sand covered by a loam-clay layer, emerge at the top of hills.

In the surveyed area, it is possible to observe dry arable lands cultivated with cereal and legume crop rotations on clay formations, as well as olive orchards, vineyards, small arable lands and pastures on the roughest soils. 
This area is highly sensitive to hydrogeological instability, because of its soil and climate parameters. In fact, some areas subjected to landslides and damages caused by floods and water stagnation were identified during the surveys.

\section{Nomenclature Proposed for Hydrogeological Instability Risks}

The data provided by ISPRA, together with other information given by other authorities, are fundamental for implementing appropriate strategies for reducing the hydrogeological risk through correct territory planning, structural interventions, alerting and monitoring tools, as well as territory maintenance and the best agricultural and forestry practices. All of this information should be communicated through the previously proposed Soil Cadastre.

In order to minimise surface erosion, appropriate hydraulic-forestry soil reclamations must be carried out in collection basins. After studying the basin parameters, it is possible to carry out, along the slopes, the transplanting and/or seeding of soils, terracing or building up of cagesor concrete walls or installation of retention nets to prevent rocks from falling down. Instead, the intensive works change the slope and the longitudinal outline of streams, building up thresholds and weirs, walls, gabions or side coverages along the bed, as well as repellents or panels. Moreover, appropriate agronomic techniques must be implemented, such as those described in the Code of Good Agricultural Practice [47].

Furthermore, the danger of landslides needs to be evaluated, preventing these landslides by means of hydraulic-forestry land reclamation, drainage works, the geo-referenced monitoring of crevasses on the soil surface by means of a GNSS receiver [21], and alarms (constituted by gypsum or glass inserted inside a crevasse and fixed to the walls with mastic, so that it will break when the size of crevasse increases).

According to the EU Floods Directive [34], the management of flood risk is needed when an unsustainable work exists in a site; it must be removed or changed to make it suitable for the site itself, thus minimising flood risk. Hydrological and hydrodynamic simulation tools can monitor rainfall and temperature. Another effective practice can be water canalisation, by building up banks, massive walls and canals, in order to increase the downflow capacity in the bed. Furthermore, expansion cases, artificial flood control channels and diversions can be built up to remove water from the current, even if these works are expensive and have a large environmental impact.

Finally, in order to face water stagnation, drainage works need to be built up, e.g., ditching or the use of pipes and drainage wells.

Based on the observations carried out during the surveys, it was possible to deduce the causes of hydrogeological instability aside from ongoing climate change and human activities, i.e., building up infrastructures to obstruct the downflow of the excessive water, and accelerating the degradation process of natural resources, able to minimise soil fertility.

The EU communication COM (2006)231 that addressed "thematic strategy for soil protection" [48] stated that, in Sicily, threats are caused by incorrect crop operations and unethical agricultural and forestry practices, excessive soil exploitation, and the abandonment of rural areas. Therefore, human activities are factors of hydrogeological instability. Thus, sustainable human activities can prevent from hydrogeological instability and farmers must be educated and become aware of these activities, as well as addressed to the principles of Soil Cadastre, only if their management is harmful to the environment. Moreover, farmers are increasingly aware of acting with maximum safety by reducing, for instance, tractor overturning risks in hilly areas, and thus work accidents and expenses for medical and hospital care [49].

All the best agricultural practices able to protect soil structure will be promoted: minimum tillage and zero tillage, permanent soil cover with grass, and diversified crop rotations and associations, leaving crop residues in the soil.

These best practices will:

- $\quad$ Maintain the active soil layer;

- Increase water retention capacity; 
- Maintain soil organic matter and reduce the emissions of greenhouse gases (GHGs) and the consumption of fuel;

- Increase carbon sequestration in the soil and, therefore, reduce the emission of $\mathrm{CO}_{2}$ into the atmosphere.

Therefore, in order to specify the causes of hydrogeological instability due to human activities, a nomenclature is proposed for the instability caused by downflow water. The proposed nomenclature allows brief communications with farmers, reminding them of more sustainable soil management. This nomenclature includes four main risks, which are distinguished according to the risk causes. The first risk occurs in environments where human activities are minimal (woods, forests and mountain pastures), while the other three ricks are caused by incorrect human activities. The structure of this nomenclature proposed for hydrogeological instability is shown in Table 1.

Table 1. Nomenclature proposed for hydrogeological instability risks, based on the three surveyed case studies.

\begin{tabular}{ll}
\hline \multicolumn{1}{c}{ Risk Type } & \multicolumn{1}{c}{ Risk Causes } \\
\hline Hydrogeological risk & $\begin{array}{l}\text { Natural factors in woods, forests and } \\
\text { mountain pastures. }\end{array}$ \\
\hline & $\begin{array}{l}\text { Crop selection (e.g., cereal and legume crop } \\
\text { rotations on arable lands) is not suitable for the } \\
\text { within-field soil and climate parameters or the } \\
\text { presence of springs (hydrological limit) with } \\
\text { mydraulic-pedological farming risk }\end{array}$ \\
& $\begin{array}{l}\text { ming drainage (a surface levelling must be } \\
\text { carried out by means of bulldozer in September) in } \\
\text { clay soils with a high gradient (pedological limit). } \\
\text { Landslides occur every winter. }\end{array}$
\end{tabular}

Building up infrastructures not suitable for the surrounding environment, as they change the downflow of shallow water, for example:

- $\quad$ Reduction in the bed of narrow valleys or rivers for agricultural purposes;

- $\quad$ Protection grills of access to road bridges not correctly placed and subsequent blockage of meshes with scrub, which is transported when the river floods by breeching dams and

Hydraulic-infrastructural risk overflowing onto roads and in soils;

- Bridges built up for joining the two banks of a narrow valley or river with a canal flow rate not suitable for the maximum flow at that location, causing overflow;

- Walls or fences of estates changing the downflow lines;

- Driveways upstream blocking water downflow in the adjacent cadastral parcels;

- Canalisations changing water downflow.

Hydraulic-infrastructural-pedologicalmanagement risk
This risk occurs where crop operations are not suitable for the soil and climate parameters, e.g., up-down soil tillage along slopes, causing water erosion, are carried out, while the soil use is correct and field improvements change water downflow.

\subsection{Hydrogeological Risk}

The hydrogeological risk is caused by natural factors, e.g., collapse landslides in a calcareous cliff in uninhabited areas and erosion along a marly-calcareous slope. These are generally events that happen slowly without becoming disastrous. In the case of erosion 
along a marly-calcareous slope, the amount of lost soil mass is generally almost equal to the original one.

\subsection{Hydraulic-Pedological-Farming Risk}

The hydraulic-pedological-farming risk is caused by incorrect crop selection, which is not suitable for the soil and climate parameters. This risk can happen, for instance, on a hilly slope with a clay vertisol type with a landslide (with different fronts), when the arable land is cultivated with a cereal-legume crop rotation. The landslide occurs during the winter, while the field owner or manager carries out surface levelling, by means of a bulldozer, during the summer, in order to cultivate crops unsuitable for the soil (unsustainable soil use). During the observation of the part of the area affected by the landslide, a rift line was identified along the curves with the same altitude: it allowed to trigger the landslide itself. The cereal and legume crop rotation cultivated on these arable lands causes soil degradation, which is accelerated by missing soil reclamation, an unsuitable drainage network and ditching (aimed at removing downflow water from the landslide area), and up-down soil ploughing.

Therefore, soil reclamation is needed, by performing temporary ditching or building up an everlasting drainage network.

Moreover, soil contour ploughing is needed. Yet, the plough mouldboard must let the soil slice rotate upstream in order to compensate for soil erosion, moving it downstream. Another option can be the implementation of conservative soil tillage techniques, e.g., minimum tillage, by means of soil implements different from the plough, e.g., subsoiler. This implement is able to cut the soil along a line parallel to the field plane, without soil slice rotation, in order to prevent soil erosion, and thus restore a sustainable soil use [43].

\subsection{Hydraulic-Infrastructural Risk}

The hydraulic-infrastructural risk is caused by the presence of infrastructures not suitable for the site. This risk type is widespread in Sicily because of the high degree of unauthorised development and the low attention paid by planners to territory vulnerability. These works do not let the water downflow freely inside the hydrographic network; the water changes its path and speed. Damages caused by the infrastructures existing in a narrow valley were observed during the surveys after a rainfall, which was slightly more intense than usual, at the end of winter 2015. At the top, the slope in a narrow valley increased the downflow speed, by allowing a continuous transportation of stony materials that caused damages to the deposits on agricultural soils. Downstream, it was possible to observe the formation of a new downflow line, parallel to the narrow valley of the hydrographic network. This downflow line was not clean and was narrow for the deposit of calcareous rocks, moved by stone removal. Moreover, downstream, it was possible to observe a metal grill protecting the manhole of a road, obstructed by soil materials, stones and scrub, which had a barrier and caused water overflow onto the road. This happened because the periodical maintenance of manholes and downflow lines was not carried out, and the grill was badly designed and placed. In fact, if a grill suitable for the site was placed, it would have allowed a free water downflow. In this case, the grill, protecting the manhole for the safety of pedestrians, should have been built up like a low cage and placed higher (almost on the border of the opening of road bridge). The situation became worse in the surroundings, where another infrastructure was observed in another narrow valley: it was a manhole drowned in a concrete block, located inside the narrow valley for crossing the water stream and reaching an insulated field. The opening of the manhole was partly buried and the water of the narrow valley overflowed and flooded agricultural fields during the same rain. Then, the water dug a side of the concrete block and circumvented the infrastructure. The opening of the manhole was too small, as it was not able to receive the overflow waves of downflow water in that location. The water of the narrow valley flooded a provincial road, which was unmaintained. In fact, the areas of ditches along the borders of the road were covered by plants, impeding the flow of water towards the entrances of 
the bridge located downstream. Along its downflow, the water reached a flat field that was flooded. This water stagnation caused root asphyxiation of the plants and, therefore, minimised the soil productivity. In this field, the downflow was obstructed by a driveway and, therefore, the field itself remained uncultivated and abandoned for many years, as the faulty drainage impeded a normal crop growth and production. Water stagnation could be avoided by placing a pipe below the driveway to remove the water to a depth sufficient for guaranteeing a soil explorable by plant roots for at least $1 \mathrm{~m}$ [50]. The flooded water reached a small field having a low slope and a short downflow line. Downstream the wall worked as a barrier, by collecting the water upstream until the overflow. In a vertex of the hydrographic network, a detachment fracture was observed from the wall to the other side. Outside the field, in the opposite vertex, another crack, caused by high water pressure, was observed. Moreover, the speed reached by the water in the field eroded its surface (sheet erosion) and caused some furrows that joined downstream, creating a deeper furrow. Meanwhile, downstream in the flattest part of the field, the water deposited the subtle soil mass, in order to create some dunes.

During a second survey, carried out in autumn 2016, it was possible to observe that a second wall was built during the summer, along a side of the road, in order to block the flood wave and deviate it along the road itself. Works such as road bridges built up in the narrow valleys must be kept efficient by means of trees along the river banks and free bed. Moreover, all the roads should be subjected to periodical and appropriate maintenance.

\subsection{Hydraulic-Infrastructural-Pedological-Management Risk}

Finally, the hydraulic-infrastructural-pedological-management risk, occurring where the selected cultivated plant species are suitable for the environment, is caused by incorrect crop management. This risk occurs in soils along the hilly calcarenite slopes cultivated with olive orchards, where up-down soil tillage causes shallow water erosion About ten years before the performed surveys (around 2005), an olive orchard with up-down oriented rows replaced a vineyard with rows oriented normally to the line of maximum slope of the surveyed field; therefore, water downflow was promoted in its flat area, while soil erosion was prevented in its sloping areas. This changed the downflow line of shallow water beneath the surface, so that it was diverted towards the wall of the neighbour, damaging it. The field improvement had a high environmental impact on the field itself, so that the original downflow line should be restored.

\section{Implementation of the Proposed Nomenclature of Hydrological Instability Risks within Soil Cadastre}

The surveys carried out allowed to understand once more that human activities, which are not suitable for certain sites, cause the different types of hydrogeological instability.

The most harmful human activities identified were concerned with building up infrastructures unsuitable for the site, incorrect crop selection and planning of field improvements, and the implemented mechanised crop operations. In fact, in the case of hydraulic-pedological-farming risk, up-down soil ploughing must be replaced by contour ploughing: the plough mouldboard must let the soil slice rotate upstream, in order to compensate for soil erosion, moving it downstream. Another option could be minimum tillage, e.g., by means of a subsoiler [43].

Nowadays, the need to make the field manager aware of their role is paramount, as they have the great responsibility to implement sustainable soil use. In fact, the field manager must select the appropriate agricultural machines and implements needed to carry out the best mechanisation practices.

The nomenclature proposed for hydrological instability risks in this work, and the recommendations included in the previously proposed Soil Cadastral Certificate, suggest to the field manager the best practices that could be implemented. In fact, in a hydrographic network, the constructions needed to regulate water downflow must be designed by a professional, and the downflow lines must be kept without diverting water to another 
sub-basin. Moreover, the previously proposed Soil Cadastral Certificate is also useful for communicating the reasons for the current unstainable soil use or management to the field owner or manager. The implementation of these principles educates the farmer and prevents environmental risks, in order to make territories safe without damages to the environment, people and their infrastructures.

Therefore, when hydrogeological instability is caused by human activities, mechanised crop operations, i.e., conservative soil tillage, and the Soil Cadastral Certificate are paramount instruments for implementing environmental sustainability.

In fact, the soils of Sicily, similar to those of other regions of Italy, are subjected to a high degradation, because of compaction and erosion, often caused by unsustainable human activities.

The effects of water erosion, mainly caused by human activity, are widespread in Sicily.

In order to guide the field owner or manager towards sustainable soil use, a nomenclature for hydrogeological risks is proposed in this work.

This nomenclature aims to summarise hydrogeological risk types that have been well known from a long time. Moreover, this nomenclature can immediately communicate risks, eventually making the soil use or management of some parcels unsustainable to the farmer. Therefore, sustainable soil use and management must be uniformly spread in every cadastral parcel of every territory.

In the future, the proposed list of hydrogeological risk types will be longer, because it will include the risks that are yet to be discovered.

The proposed nomenclature could be used by government bodies, e.g., ministries, regional departments and municipalities, for urban and territorial planning, i.e., for planning actions that aim to prevent or minimise hydrological instability in the relevant urban and suburban territories, according to the risk type existing in each area.

The innovative Soil Cadastre [5] will be a paramount instrument for promoting sustainable soil uses, as it will be able to inform farmers of unsustainable soil uses and management. Moreover, the field owner or manager will receive recommendations on the best mechanisation practices to be performed, i.e., conservative soil tillage, e.g., contour ploughing with upstream soil slice rotation or minimum tillage by means of a subsoiler. At the same time, the farmers who carry out sustainable activities could be rewarded. If a natural disaster happens, the above Soil Cadastre will quickly and easily allow public interventions to be managed and implemented; the parcel owner could be provided with a fair allowance without a written application, according to the so-called bureaucratic simplification [30].

This will allow humans to continue adopting a positive approach to the environment, with an increase sensitivity towards ecosystems and an awareness of their vulnerability. Thus, at the same time, farmers will obtain economic benefits from the sale of the assets produced by the environment, as well as from the management of their fields by means of a prize [5].

Author Contributions: Conceptualisation, A.C. and S.R.; methodology, D.P. and S.R.; validation, S.R.; formal analysis, D.P. and S.R.; investigation, D.P.; resources, A.C., C.G. and S.R.; data curation, D.P. and S.R.; writing-Original draft preparation, D.P., A.C., C.G. and S.R.; writing-Review and editing, A.C., C.G. and S.R. All authors have read and agreed to the published version of the manuscript.

Funding: This research received no external funding.

Informed Consent Statement: All the authors agree on the informed consent statement.

Conflicts of Interest: The authors declare no conflict of interest.

\section{References}

1. Costantini, E.A.C.; Castelli, F.; Raimondi, S.; Lorenzoni, P. Assessing soil moisture regimes with traditional and new methods. Soil Sci. Soc. Am. J. 2002, 66, 1889-1896. [CrossRef]

2. Brundtland, G.H. Report of the World Commission on Environment and Development: Our Common Future; United Nations: New York, NY, USA, 1987; pp. 1-247. 
3. Raimondi, S.; Comparetti, A.; Greco, C.; Juostas, A.; Pirrone, A. The evaluation of urban soils aimed at the sustainability of plants in public and private flowerbeds. In Rivista di Studi sulla Sostenibilita; FrancoAngeli: Edizioni, Italy, 2019; Volume 2, pp. 391-403. [CrossRef]

4. $\quad$ Egli, M.; Gristina, L.; Wiesenberg, G.L.B.; Civantos, J.M.M.; Rotolo, A.; Novara, A.; Brandovà, D.; Raimondi, S. From pedologic indications to archaeological reconstruction: Deciphering land use in the Islamic period in the Baida district (nord-western Sicily). J. Archaeol. Sci. 2013, 40, 2670-2685. [CrossRef]

5. Raimondi, S. The structure of Soil Cadastre. a model of soil inventory for environmental, social, economic and taxation purposes in a globalised market. EQA-Environ. Qual./Qual. L'environ./Qual. Ambient. 2017, 25, 49-63. [CrossRef]

6. Mateo-Sagasta, J.; Marjani Zadeh, S.; Turral, H.; Burke, J. Water Pollution from Agriculture: A Global Review. Executive Summary; Food and Agriculture Organization of the United Nations Rome International Water Management Institute (Water Land and Ecosystems Research Program Colombo): Rome, Italy, 2017; pp. 1-35.

7. ISPRA-Istituto Superiore per la Protezione e la Ricerca Ambientale (Higher Institute for Environmental Protection and Research); Sistema Nazionale per la Protezione dell'Ambiente (National System for Environment Protection); ReNDIS 2020. La Difesa del Suolo in Vent'anni di Monitoraggio ISPRA Sugli Interventi per la Mitigazione del Rischio Idrogeologico (The Soil Protection in Twenty Years of ISPRA Monitoring on the Interventions for Mitigating Hydrogeological Risk); Report 328/2020; ISPRA: Rome, Italy, 2020; pp. 1-174. Available online: https://www.isprambiente.gov.it/it/pubblicazioni/rapporti/rapporto-rendis-2020 (accessed on 9 December 2021).

8. Haines-Young, R.; Potschin, M.B. The links between biodiversity, ecosystem services and human well-being. In Ecosystem Ecology: A New Synthesis; Raffaelli, D.G., Frid, C.L.J., Eds.; Cambridge University Press: Cambridge, UK, 2010; pp. 110-139.

9. Egli, M.; Plötze, M.; Tikhomirov, D.; Kraut, T.; Wiesenberg, G.L.B.; Lauria, G.; Raimondi, S. Soil development on sediments and evaporites of the Messinian crisis. Catena 2020, 187, 1-16. [CrossRef]

10. Egli, M.; Hunt, A.G.; Dahms, D.; Raab, G.; Derungs, C.; Raimondi, S.; Yu, F. Prediction of Soil Formation as a Function of Age Using the Percolation Theory Approach. Front. Environ. Sci. 2018, 6, 1-21. [CrossRef]

11. Mirabella, A.; Egli, M.; Raimondi, S.; Giaccai, D. Origin of clay minerals in soils on pyroclastic deposits in the island of Lipari (Italy). Clays Clay Min. 2005, 53, 409-421. [CrossRef]

12. Egli, M.; Alioth, L.; Mirabella, A.; Raimondi, S.; Nater, M.; Verel, R. Effect of climate and vegetation on soil organic carbon, humus fractions, allophanes, imogolite, Caolinite, and oxyhydroxides in volcanic soils of Etna (Sicily). Soil Sci. 2007, 172, 673-691. [CrossRef]

13. Egli, M.; Nater, M.; Mirabella, A.; Raimondi, S.; Plotze, M.; Alioth, L. Clay minerals, oxyhydroxide formation, element leaching and humus development in volcanic soil. Geoderma 2008, 143, 101-114. [CrossRef]

14. Egli, M.; Filip, D.; Mavris, C.; Fischer, B.; Götze, J.; Raimondi, S.; Seibert, J. Rapid transformation of inorganic to organic and plant-available phosphorous in soils of a glacier forefield. Geoderma 2012, 189-190, 215-226. [CrossRef]

15. Egli, M.; Mastrolonardo, G.; Seiler, R.; Raimondi, S.; Favilli, F.; Crimi, V.; Krebs, R.; Cherubini, P.; Certini, G. Charcoal and stable soil organic matter as indicators of fire frequency, climate and past vegetation in volcanic soil of Mt. Etna, Sicily. Catena 2012, 88 , 14-26. [CrossRef]

16. Raab, G.; Halpern, D.; Scarciglia, F.; Raimondi, S.; Norton, K.; Pettke, T.; Hermann, J.; Decastro Portes, R.; Aguillar Sanchez, A.M Linking tephrochronology and soil characteristics in the Sila and Nebrodi mountains, Italy. Catena 2017, 158, 266-285. [CrossRef]

17. Raimondi, S.; Puccio, D.; Egli, M. An extra-urban soil cadastre for Italy: A first guide for the introduction of soil information. EQA-Environ. Qual./Qual. L'environ./Qual. Ambient. 2020, 39, 1-10. [CrossRef]

18. Carrara, M.; Castrignanò, A.; Comparetti, A.; Febo, P.; Orlando, S. Multivariate geostatistics for assessing and predicting soil compaction. In Proceedings of the 5th European Conference on Precision Agriculture (5ECPA), Uppsala, Sweden, 9-12 June 2005; pp. 723-730.

19. Carrara, M.; Castrignanò, A.; Comparetti, A.; Febo, P.; Orlando, S. Mapping of penetrometer resistance in relation to tractor traffic using multivariate geostatistics. Geoderma 2007, 142, 294-307. [CrossRef]

20. Comparetti, A.; Febo, P.; Orlando, S. A system for the real-time geo-referenced measurement of soil parameters. Bulg. J. Agric. Sci. 2013, 19, 1253-1257.

21. Catania, P.; Comparetti, A.; Febo, P.; Morello, G.; Orlando, S.; Roma, E.; Vallone, M. Positioning accuracy comparison of GNSS receivers used for mapping and guidance of agricultural machines. Agronomy 2020, 10, 924. [CrossRef]

22. Bentaher, H.; Hamza, E.; Kantchev, G.; Maalej, A.; Arnold, W. Three-point hitch-mechanism instrumentation for tillage power optimization. Biosyst. Eng. 2008, 100, 24-30. [CrossRef]

23. Gill, W.R.; Vanden Berg, G.E. Soil Dynamics in Tillage and Traction; Agricultural Research Service, US Department of Agriculture: Washington, DC, USA, 1967.

24. Godwin, R.J. A review of the effect of implement geometry on soil failure and implement forces. Soil Tillage Res. 2007, 97, 331-340. [CrossRef]

25. McKyes, E. Soil cutting and tillage. In Developments in Agricultural Engineering; Elsevier: Amsterdam, The Netherlands, 1985; Volume 7.

26. Niyamapa, T.; Salokhe, V.M. Force and pressure distribution under vibratory tillage tool. J. Terramech. 2000, 37, 139-150. [CrossRef]

27. Klingebiel, A.A.; Montgomery, P.H. Land Capability Classification; USDA Agriculture Handbook 210; US Department of Agriculture: Washington, DC, USA, 1961. 
28. Puccio, D.; Raimondi, S. The Enviromental Problems of the Piana del Signore (Gela, Sicily) for a Correct Agronomic, Cultural and Landscape Upgrading and Enhancement of the Area. EQA-Environ. Qual./Qual. L'environ./Qual. Ambient. 2017, 25, 19-32. [CrossRef]

29. Scacco, A.; Verzera, A.; Lanza, C.M.; Sparacio, A.; Genna, G.; Raimondi, S.; Tripodi, G.; Dima, G. Influence of soil salinity on sensory characteristics and volatile aroma compounds of Nero d'Avola wine. Am. J. Enol. Viticult. 2010, 61, 498-505. [CrossRef]

30. Comparetti, A.; Raimondi, S. Cadastral models in EU Member States. EQA-Environ. Qual./Qual. L'environ./Qual. Ambient. 2019, 33, 55-78. [CrossRef]

31. Raimondi, S.; Attard, G.; Comparetti, A.; Greco, C. Towards the European harmonisation of a Soil Cadastre inventory as a tool for environmental, social, economic, legal and taxation purposes. In Rivista di Studi sulla Sostenibilita; FrancoAngeli: Edizioni, Italy, 2019; Volume 2, pp. 275-297. [CrossRef]

32. Pinna, S. Rischi Ambientali e Difesa del Territorio (Environmental Risks and Territory Protection); Franco Angeli: Milan, Italy, 2002; pp. 1-176.

33. Gisotti, G. Il Dissesto Idrogeologico. Previsione, Prevenzione e Mitigazione del Rischio (The Soil Instability. Risk Forecast, Prevention and Mitigation); Dario Flaccovio: Palermo, Italy, 2012; pp. 1-640.

34. EU. Directive 2007/60/EC of the European Parliament and of the Council of 23 October 2007 on the Assessment and Management of Flood Risks; 2007; pp. 1-8. Available online: https:/ / eur-lex.europa.eu/legal-content/EN/TXT/PDF/?uri=CELEX:32007L0060\&from= EN (accessed on 1 September 2020).

35. Horvat, Z.; Filipovic, D.; Kosutic, S.; Emert, R. Reduction of mouldboard plough share wear by a combination technique of hardfacing. Tribol. Int. 2008, 41, 778-782. [CrossRef]

36. Mattetti, M.; Varani, M.; Molari, G.; Morelli, F. Influence of the speed on soil-pressure over a plough. Biosyst. Eng. 2017, 156, 136-147. [CrossRef]

37. Mayauskas, I.S. Investigation of the pressure distribution on the surface of a plow share in work. J. Agric. Eng. Res. 1958, 4, 186-190.

38. Natsis, A.; Papadakis, G.; Pitsilis, J. The influence of soil type, soil water and share sharpness of a mouldboard plough on energy consumption, rate of work and tillage quality. J. Agric. Eng. Res. 1999, 72, 171-176. [CrossRef]

39. Owende, P.M.O.; Ward, S.M. Characteristic loading of light mouldboard ploughs at slow speeds. J. Terramech. 1996, 33, 29-53. [CrossRef]

40. Rucins, A.; Vilde, A.J.; Nowak, J. Impact of the Share Inclination Angle on the Ploughing Resistance; TEKA Commission of Motorization and Power Industry in Agriculture, Polish Academy of Sciences Branch in Lublin: Lublin, Poland, 2007; Volume VII, pp. 199-209.

41. Shchuchkin, N. Ploughs and Shallow Ploughs; Mechanical Engineering: Moscow, Russia, 1982.

42. Vilde, A. Profilograms of share-mouldboards surfaces of some typical plough bodies. In Proceedings of the 11th International Scientific Conference "Engineering for Rural Development", Jelgava, Latvia, 24-25 May 2012; Volume 11, pp. 81-87.

43. Peruzzi, A.; Sartori, L. Guida Alla Scelta ed All'impiego Delle Attrezzature per la Lavorazione del Terreno (Guide for Selecting and Using Soil Tillage Tools); Edagricole: Bologna, Italy, 1997; pp. 1-236.

44. Godwin, R.J.; Spoor, G. Soil failure with narrow tines. J. Agric. Eng. Res. 1977, 22, 213-228. [CrossRef]

45. Bayhan, Y. Reduction of wear via hardfacing of chisel ploughshare. Tribol. Int. 2006, 39, 570-574. [CrossRef]

46. Regione Siciliana. (Sicilian Region)-Assessorato Agricoltura e Foreste-Gruppo IV-Servizi Allo Sviluppo-Unità di Agrometeorologia. Climatologia della Sicilia (Climatology of Sicily): Sicilian Region, Palermo, Italy. pp. 1-643. Available online: http:/ / www.sias.regione.sicilia.it/pdf/Climatologia_sicilia.pdf (accessed on 1 September 2020).

47. Ministero delle Politiche Agricole e Forestali (Ministry of Agricultural and Forestry Policies). Decreto Ministeriale 19 aprile 1999-Approvazione del Codice di Buona Pratica Agricola. (Italian Ministerial Decree of 19 April 1999—approval of the code of good agricultural practice)—GU Serie Generale n. 102 del 04-05-1999—Supplemento Ordinario n. 86). Available online: https://www.gazzettaufficiale.it/eli/id/1999/05/04/099A3435/sg (accessed on 1 September 2020).

48. Commission of The European Communities, Brussels, 22.9.2006. COM(2006)231. Communication from the Commission to the Council, the European Parliament, the European Economic and Social Committee and the Committee of the Regions-Thematic Strategy for Soil Protection; [SEC(2006)620]. [SEC(2006)1165]; pp. 1-12. Available online: https:/ / eur-lex.europa.eu/LexUriServ/LexUriServ.do? uri=COM:2006:0231:FIN:EN:PDF (accessed on 1 September 2020).

49. Pessina, D.; Facchinetti, D. Il ruolo del web nel monitoraggio degli incidenti mortali dovuti al ribaltamento dei trattori agricoli (The role of web in monitoring the deadly accidents caused by the overturning of agricultural tractors). In Proceedings of the Atti del Convegno di Medio Termine dell'Associazione Italiana di Ingegneria Agraria "Gestione e Controllo dei Sistemi Agrari e Forestali", Belgirate, Italy, 22-24 September 2011; pp. 1-6.

50. Xiao, J.; Wang, Y.; Shi, P.; Yang, L.; Chen, L.D. Potential effects of large linear pipeline construction on soil and vegetation in ecologically fragile regions. Environ. Monit. Assess. 2014, 186, 8037-8048. [CrossRef] [PubMed] 